\title{
Silage Quality of Sorghum Harvested at Different Times and Its Combination with Mixed Legumes or Concentrate Evaluated in Vitro
}

\author{
Ardiansyah $^{\mathrm{a}}$, K. G. Wiryawan ${ }^{\mathrm{b}, *}$, \& P. D. M. H. Karti ${ }^{\mathrm{b}}$ \\ aStudy Program of Nutrition and Feed Science, Faculty of Animal Science, Graduate School, \\ Bogor Agricultural University \\ ${ }^{b}$ Department of Nutrition and Feed Technology, Faculty of Animal Science, Bogor Agricultural University \\ Jalan Agatis, Kampus IPB Darmaga Bogor 16680, Indonesia \\ (Received 25-08-2015; Reviewed 09-10-2015; Accepted 19-01-2016)
}

\begin{abstract}
The experiment was designed to evaluate the silage quality of sorghum forage varieties of Citayam and BMR 3.6 strain at different harvesting times and the effectiveness of a legumes addition as a concentrate substitute in sorghum forage silage-based diets on in vitro fermentability using rumen fluid of beef cattle. Experimental design for silage quality was completely randomized design with $2 \times 3$ factorial, i.e., forage sorghum types (Citayam and BMR 3.6) and time of harvesting the forage sorghum $(85,95$, and $105 \mathrm{~d})$. Experimental design for in vitro fermentability and digestibility was randomized block design with $2 \times 2$ factorial arrangement, i.e. types of ration (with 2 levels i.e., a mixture of legumes and concentrate) and types of sorghum forage silages (with 2 levels i.e., Citayam and BMR 3.6). All silages had a good odor, color, and texture. Silage of sorghum harvested at $105 \mathrm{~d}$ had better grades and was selected for in vitro studies. The treatment had no effect on $\mathrm{pH}$ and organic matter digestibility. BMR 3.6 based silage had greater values of $\mathrm{NH}_{3}$, total VFA, rumen microbial population, methane, and dry matter digestibility. Substitution of concentrate with a mixture of legumes did not affect fermentability, microbe population and digestibility in the rumen. Silage of sorghum strain BMR 3.6 harvested at $105 \mathrm{~d}$ had a very good quality and mixing with legumes could replace concentrate in forage sorghum silage based diet on in vitro fermentability and digestibility using beef cattle rumen fluid.
\end{abstract}

Key words: BMR 3.6, Citayam, mixture of legume, silage, sorghum

\begin{abstract}
ABSTRAK
Tujuan penelitian ini ialah untuk mengevaluasi kualitas silase hijauan sorgum varietas Citayam dan galur BMR 3.6 pada umur panen yang berbeda dan mengevaluasi efektivitas campuran legum sebagai pengganti konsentrat dalam pakan berbasis silase hijauan sorgum secara in vitro menggunakan cairan rumen sapi potong. Rancangan percobaan untuk kualitas silase adalah rancangan acak lengkap faktorial $2 \times 3$, yaitu jenis hijauan sorgum (Citayam dan BMR 3.6) dan umur panen hijauan sorgum $(85,95$, dan 105 hari). Rancangan percobaan untuk fermentabilitas dan kecernaan in vitro adalah rancangan acak kelompok faktorial $2 \times 2$, yaitu jenis ransum (campuran legum dan konsentrat) dan jenis silase hijauan sorgum (Citayam dan BMR 3.6). Semua silase memiliki aroma, warna, dan tekstur yang baik. Fermentabilitas silase sorgum umur panen 105 hari memiliki nilai yang lebih baik sehingga dipilih untuk percobaan in vitro. Perlakuan tidak berpengaruh pada $\mathrm{pH}$ dan kecernaan bahan organik. Pemberian BMR 3.6 meningkatkan nilai $\mathrm{NH}_{3^{\prime}}$ VFA total, populasi mikroba rumen, produksi gas metan, dan kecernaan bahan kering. Penggantian konsentrat dengan campuran legum tidak mempengaruhi fermentabilitas, populasi mikroba, dan kecernaan di dalam rumen. Silase hijauan sorgum galur BMR 3.6 pada umur panen 105 hari memiliki kualitas yang sangat baik dan campuran legum dapat menggantikan konsentrat pada pakan berbasis silase hijauan sorgum secara in vitro menggunakan cairan rumen sapi potong.
\end{abstract}

Kata kunci: BMR 3.6, Citayam, campuran legum, silase, sorgum

*Corresponding author:

E-mail: kgwiryawan61@gmail.com 


\section{INTRODUCTION}

Farm management should be able to establish and provide a source of protein for meeting livestock needs because it is the most important and expensive component in the ration. Protein sources commonly used in ruminants are concentrates of agricultural byproducts and plantation products. However, in Indonesia, there are areas with limited availability of concentrate, requiring enormous costs in the supply of concentrate. One of alternatives that can be used to replace the concentrate is legume forage that has high crude protein content.

Legume forage has a high crude protein content i.e., 20\%-30\% (McDonald et al., 2010) and excellent legume is used as ruminant feed. The use of seasonal and annual legume hay could improve the digestibility and synthesis of microbial nitrogen (Foster et al., 2009). In addition, the use of alfalfa, white and red clover legumes increased production of $\mathrm{NH}_{3}$ and a mixture of grass sainfoin-legume could reduce the degradation of proteins and the production of methane (Niderkorn et al., 2011).

Leucaena leucocephala (lamtoro) leaves can be used as a source of protein and heat treatment of L. leucocephala could increase feed intake, nutrient digestibility, and rumen fermentability in swamp buffalo fed with ammoniated rice straw-based diet (Kang et al., 2012). L. leucocephala (tanniniferous legume) can replace Vigna unguiculata (low-tannin legume) in a complete feed without seriously affecting the characteristics of fermentation in the rumen (Hess et al., 2008). Condensed tannins (CT) of L. leucocephala was relatively low (15 mg $\mathrm{CT} / 500 \mathrm{mg} \mathrm{DM}$ ), reduced the production of $\mathrm{CH}_{4}$ (methane) by $47 \%$, but only $7 \%$ decreased in the degradation of feed dry matter (Tan et al., 2011). Gliricidia (G.) sepium has the potential to be utilized as ruminant feed supplement in Nigeria during the summer (Anele et al., 2009). G. sepium has a high crude protein (CP) content (23.2\%), and could be given as a nitrogen supplement in Napier grass-based diet for cattle which increased lactation performances (Juma et al., 2006). Indigofera (I) zollingeriana has a good digestibility of nutrients for ruminants (Abdullah \& Suharlina, 2010). I. zollingeriana has a crude protein and in vitro dry matter digestibility, respectively, $27.68 \%$ and $75.44 \%$ without fertilization and $31.31 \%$ and $85.50 \%$ by fertilization (Abdullah, 2010).

Sorghum (Sorghum bicolor L.) is a cereal plant type that has potential to be cultivated and developed in marginal and dry areas in Indonesia. Selection of sorghum as a major feed on marginal lands is the best solution in the supply of forage for ruminants. Jahanzad et al. (2013) stated that forage sorghum had higher productivity in the medium irrigation systems and low seed density. Sorghum also has a greater biomass than corn (Rocateli et al., 2012). The potential productivity of sorghum on marginal land as ruminant forages should also be supported by the types of seeds that have good quality.

Citayam and Brown midrib (BMR) 3.6 strains are genetically mutated sorghums that have superior agronomic traits. The harvest time of sorghum should be adapted to the purpose of production. There are differences in the nutrient contents of forage sorghum at the age of vegetative, early generative, until filling grain. Differences in harvest times will provide information about the nutritional values that can be used to determine a suitable harvest time of sorghum as a forage source. The abundance of sorghum production at certain harvest times needs a method of preservation to ensure the continuous availability of forage. Silage is a forage preservation method based on the lactic acid fermentation under anaerobic conditions.

Silage techniques can minimize the loss of nutrients from harvesting to storage. Lactic acid bacteria found in forages are involved in the fermentation of watersoluble carbohydrates into lactic acid and acetic acid. As a result, the $\mathrm{pH}$ of silage decreases and the activity of spoilage microbes can be inhibited. This condition will keep the silage remain well-preserved in the long term. Lactic acid bacteria with a population of $10^{6} \mathrm{CFU} / \mathrm{g}$ on silage will increase the stability of the silage after exposure to the air $(7 \mathrm{~d})$ and this condition contributes to the maintenance of nutritional value of silage from time to time (Tabacco et al., 2011) and inhibited the activity of undesirable microorganisms (Keles \& Demirci, 2011). The addition of lactic acid bacteria such as Lactobacillus plantarum and water soluble carbohydrates in silage will improve silage quality (Lima et al., 2011) and maintain the protein during fermentation, as well as increases the growth of rumen microbes (Contreras-Govea et al., 2013)

Replacement of the concentrate with a mixture of legumes and sorghum forage silage is expected to be an alternative solution to the problems of ruminant livestock development on marginal lands. This study was designed to evaluate the silage quality of sorghum forage varieties of Citayam and strain of BMR 3.6 at different harvest times and the effectiveness of legume supplementation as a concentrate substitute in fermentability of sorghum forage silage-based diets in vitro by using rumen fluid of beef cattle as fermentation media.

\section{MATERIALS AND METHODS}

\section{Silage Production}

Sorghum forage Citayam and BMR 3.6 were harvested at 85, 95, and 105 days of planting. The whole sorghum forage (stem, leaf, and grain) was chopped to a theoretical length of $3-5 \mathrm{~cm}$. L. plantarum $(1 \mathrm{~A}-2)$ inoculant $\left(1 \times 10^{10} \mathrm{CFU} / \mathrm{mL}\right)$ from the Indonesian Institute of Sciences (LIPI) in Cibinong was added $1 \%$ on each forage (1500 g each) and ensiled in jar silos of $1500 \mathrm{~g}$. After $28 \mathrm{~d}$, the silos were opened to observe physical characteristics such as silage odor, color, temperature, presence of fungi, and weight of silage. Part of silage was taken for observation of silage characteristics such as $\mathrm{pH}$, proximate referring to the AOAC (2007), and the Fleigh points (Idikut et al., 2009). All variables of the silages were scored based on the average value of each treatment in order to obtain the best combination of silage. The best combination of silage will be selected as a source of forage in in vitro experiments. 


\section{In Vitro Fermentation}

In vitro fermentation and digestibility was conducted by using the method of Tilley \& Terry (1963). Into each fermentation tube, $40 \mathrm{~mL}$ of McDougall buffer, $0.5 \mathrm{mg}$ of treatment ration, and $10 \mathrm{~mL}$ of rumen fluid were added and the mixtures were incubated at $39^{\circ} \mathrm{C}$. Fresh rumen fluid of fistulated beef cattle was obtained from Indonesian Institute of Sciences (LIPI). The treatment (Table 1) consisted of $30 \%$ isoprotein rations (concentrate or mixed legumes) and 70\% sorghum forage silage for bulls with the weight of $250 \mathrm{~kg}$ and weight gain $0.75-1.00 \mathrm{~kg} / \mathrm{d}$ containing $10.69 \%-11.69 \% \mathrm{CP}$ and $57.33 \%-66.67 \%$ Total Digestible Nutrients (TDN) (Kearl, 1982). Samples were taken after $4 \mathrm{~h}$ incubation for analysis of $\mathrm{pH}$, partial VFA using gas chromatography (GC) and gas production of methane (Moss et al., 2000), $\mathrm{NH}_{3}$ concentration with micro diffusion Conway method, microbial populations (Ogimoto \& Imai, 1981), and after $48 \mathrm{~h}$ incubation for dry matter and organic matter digestibility analysis.

\section{Statistical Analysis}

The experimental design for evaluating silage quality was completely randomized design with a $2 \times 3$ factorial, i.e., sorghum forage types (Citayam and BMR 3.6) and time of harvesting sorghum forage (85, 95, and 105 d). Experimental design for in vitro fermentability and digestibility was a randomized block design with $2 \times 2$ factorial, i.e., types of ration mixtures of legumes (L. leucocephala, G. sepium, and I. zollingeriana) and concentrates (rice brand, tofu waste, urea, and premix) and type of sorghum forage silage (Citayam and BMR 3.6) with 3 replications. The data obtained were analyzed by using analysis of variance (ANOVA). Duncan multiple range test was used to test the significant interaction. If there was significant effect of the main factor (sorghum forage, ration or silage types), the data was examined with T test. Polynomial orthogonal was used to determine the effect of harvest time (Steel \& Torrie, 1997).

Table 1. Nutrient composition of experimental feed (dry matter basis) with $70 \%$ sorghum silage and $30 \%$ ration mixture

\begin{tabular}{lrrrrr}
\hline \multirow{2}{*}{ Nutrients (\%) } & \multicolumn{2}{c}{ Citayam } & & \multicolumn{2}{c}{ BMR 3.6 } \\
\cline { 2 - 3 } \cline { 5 - 6 } & $\begin{array}{c}\text { Mixed } \\
\text { legumes }\end{array}$ & Concentrate & & $\begin{array}{c}\text { Mixed } \\
\text { legumes }\end{array}$ & Concentrate \\
\hline Ash & 6.91 & 6.20 & & 5.99 & 5.37 \\
Crude protein (CP) & 11.20 & 11.48 & & 11.96 & 11.47 \\
Crude fiber (CF) & 27.99 & 29.95 & & 27.40 & 27.59 \\
Ether extract (EE) & 1.51 & 3.51 & & 2.06 & 3.73 \\
Nitrogen free & 51.89 & 48.78 & & 52.09 & 48.92 \\
extract (NFE) & & & & & \\
Total digestible & 61.34 & 62.37 & & 62.97 & 62.23 \\
nutrient (TDN)* & & & & \\
\hline
\end{tabular}

Note: $*$ \% TDN for silage $=-72.943+4.675(\mathrm{CF})-1.28(\mathrm{EE})+1.611(\mathrm{NEF})$ $+0.497(\mathrm{CP})-0.044(\mathrm{CF}) 2-0.76(\mathrm{EE}) 2-0.039(\mathrm{CF})(\mathrm{NFE})+0.087$ (EE) (NFE) - $0.152(\mathrm{EE})(\mathrm{CP})+0.074(\mathrm{EE}) 2(\mathrm{CP})$; \% TDN for Ration $=-133.726+0.254(\mathrm{CF})+19.593(\mathrm{EE})+2.784(\mathrm{NEF})+2.315(\mathrm{CP})+$ 0.028 (CF) $2-0.341$ (EE)2 - 0.008 (CF) (NFE) - 0.215 (EE) (NFE) $0.193(\mathrm{EE})(\mathrm{CP})+0.004(\mathrm{EE}) 2(\mathrm{CP})$ Hartadi et al. $(1980)$.

\section{RESULTS AND DISCUSSION}

\section{Characteristics and Nutrients Quality of Silages}

All silages had good odor, color, and texture. These parameters indicated that the silage fermentation was conducted very well. Based on Table 2, silage had a low $\mathrm{pH}$ at 3.78. Different types of sorghum and harvesting times affected the $\mathrm{pH}$ value. All types of sorghum showed good $\mathrm{pH}$ values when harvested above the age of $95 \mathrm{~d}(\mathrm{P}<0.05)$. The quality of silage fermentation can also be seen from the Fleigh points: different types of sorghum and harvest time affected the Fleigh points ( $P$ $<0.05$ ). Fleigh points denote that values between 85 and 100 , very good quality; 60 and 80, good quality; 55 and 60 , moderate quality; 25 and 40, satisfying quality; $<20$, worthless (Idikut et al., 2009). The high value of Fleigh points showed a good level of fermentation, all types of sorghum harvested over the age of $95 \mathrm{~d}$ had Fleigh points above 85 . The content of silage $\mathrm{CP}$ was affected by the type of sorghum and age of harvest $(\mathrm{P}<0.01)$. The content of silage crude fiber (CF) was affected by the interaction between the type of sorghum and harvesting age $(\mathrm{P}<0.05)$. The content of TDN was affected by the type of sorghum $(\mathrm{P}<0.01)$ and harvesting age with quadratic curve $\left(\mathrm{TDN}=84.732-0.717 \mathrm{~A}+0.004 \mathrm{~A}^{2}\right)$ based on polynomial test $(\mathrm{P}<0.05)$.

In the beginning of fermentation process, there was a high microbial diversity until the end of the silage process. Microbial diversity was dominated by lactic acid bacteria; one is L. plantarum. Lactic acid bacteria contained in the silage decreased the $\mathrm{pH}$ of the silage (Ridwan et al., 2015). A low pH value in all silages was due to the effect of the addition of lactic acid bacteria i.e., L. plantarum. The use of L. plantarum in silage fermentation improved the quality, reduced $\mathrm{pH}$, increased lactic acid content, and inhibited the growth of undesirable microbes such as fungi, coliform bacteria, and clostridia after 30 and 60 days period of storage (Tohno et al., 2012). Yuan et al. (2015) stated the addition of inoculants L. plantarum in the total mixed ration silage decreased the $\mathrm{pH}$ more than the other additives. Sorghums that were older than $95 \mathrm{~d}$ belong to the generative phase, a process of filling and ripening of grain. Forage sorghum silage used in this study, one of them older than $95 \mathrm{~d}$, so it had grain. Grains have high carbohydrate content. The availability of carbohydrates as a substrate for lactic acid bacteria to produce organic acids especially lactic acid (Emanuel et al., 2005) which cause the $\mathrm{pH}$ to decrease and inhibit the development of butyric bacteria. Inoculant should be given to forage sorghum with older ages to produce a better silage (Thomas et al., 2013).

Citayam had lower CP than BMR 3.6. Longer harvest time decreased $\mathrm{CP}$ of silage. BMR 3.6 harvested at the age of $85 \mathrm{~d}$ had the best $\mathrm{CP}$ content compared with other combinations. BMR 3.6 harvested more than 85 $\mathrm{d}$ had the same quality as Citayam harvested at $85 \mathrm{~d}$. Abdelhadi \& Tricarico (2009) stated that harvesting sorghum in milk stage would increase the content of CP.

CF of BMR 3.6 was the lowest compared with other combinations. CF of Citayam was higher than the BMR 
3.6. BMR 3.6 is a type of sorghum mutation that is selected for animal feed because of a lower content of CF. Based on Miron et al. (2005), the fraction of CF is primarily lignin. In BMR silage, the lignin was smaller than the other type of sorghum.

BMR 3.6 had greater TDN than the Citayam and this fact could be due to the content of the CF of Citayam that was higher than the other. The high content of CF was the inhibitor factor of digestibility. Harvesting sorghum at the age of more than 90-105 d after planting could increase TDN. Pereira et al. (2007) stated that an increase in the TDN content of sorghum silage-based rations could be related to an increase in carbohydrate content. At the age of $90 \mathrm{~d}$, sorghum is in the early phases of the formation of grain that is a source of carbohydrate.

\section{In Vitro Fermentability}

The average $\mathrm{pH}$, ammonia $\left(\mathrm{NH}_{3}\right)$, and total volatile fatty acids (VFA) concentrations are presented in Table 3. The type of sorghum at harvest time of 105 days and the replacement of concentrate with mix legumes did not affect rumen $\mathrm{pH}$. The concentration of $\mathrm{NH}_{3}$ was only influenced by the type of sorghum silage $(\mathrm{P}<0.01)$. The concentration of VFA was also only influenced by the type of sorghum silage $(\mathrm{P}<0.01)$. Mean concentrations of partial VFA, the ratio of acetic : propionic and methane are presented in Table 4 . Rations only affected the concentration of acetic acid $(\mathrm{P}<0.05)$, butyric acid $(\mathrm{P}<0.01)$, and the ratio of acetic acid: propionic acid $(\mathrm{P}<0.05)$. Sorghum types affected the production of methane gas $(\mathrm{P}<0.05)$.

Rumen $\mathrm{pH}$ determines the rumen condition that affects the growth of rumen microbes and rumen fermen-

Table 2. Characteristics and nutrient content of silages with different types of sorghum harvested at different time

\begin{tabular}{|c|c|c|c|c|c|}
\hline \multirow{2}{*}{ Variables } & \multirow{2}{*}{ Sorghum types } & \multicolumn{3}{|c|}{ Harvested time (d) } & \multirow{2}{*}{$\begin{array}{c}\text { Mean of sorghum } \\
\text { types }\end{array}$} \\
\hline & & 85 & 95 & 105 & \\
\hline \multirow[t]{3}{*}{$\mathrm{pH}$} & Citayam & $4.08 \pm 0.09^{\mathrm{b}}$ & $3.48 \pm 0.11^{\mathrm{a}}$ & $3.65 \pm 0.04^{\mathrm{a}}$ & $3.74 \pm 0.28$ \\
\hline & BMR 3.6 & $4.38 \pm 0.22^{c}$ & $3.49 \pm 0.01^{\mathrm{a}}$ & $3.61 \pm 0.02^{\mathrm{a}}$ & $3.83 \pm 0.43$ \\
\hline & Mean of harvest age & $4.23 \pm 0.22$ & $3.48 \pm 0.07$ & $3.63 \pm 0.04$ & \\
\hline \multirow[t]{3}{*}{ Dry matter } & Citayam & $93.98 \pm 0.53$ & $91.80 \pm 0.47$ & $90.89 \pm 0.49$ & $92.23 \pm 1.59^{\mathrm{b}}$ \\
\hline & BMR 3.6 & $93.43 \pm 1.68$ & $91.00 \pm 0.47$ & $90.46 \pm 0.59$ & $91.63 \pm 1.59^{\mathrm{a}}$ \\
\hline & Mean of harvest age & $93.71 \pm 0.39$ & $91.40 \pm 0.75$ & $90.67 \pm 0.31$ & $91.93 \pm 1.46$ \\
\hline \multirow[t]{3}{*}{ Fleigh points } & Citayam & $74.13 \pm 5.35^{\mathrm{b}}$ & $98.98 \pm 5.03^{c}$ & $96.72 \pm 1.18^{\mathrm{c}}$ & $89.94 \pm 12.47$ \\
\hline & BMR 3.6 & $58.21 \pm 6.65^{\mathrm{a}}$ & $94.45 \pm 1.14^{\mathrm{c}}$ & $93.15 \pm 1.36^{c}$ & $81.93 \pm 18.13$ \\
\hline & Mean of harvest age & $66.17 \pm 10.25$ & $96.71 \pm 4.10$ & $94.93 \pm 2.26$ & \\
\hline \multirow[t]{3}{*}{ Crude protein (\%) } & Citayam & $7.56 \pm 0.29^{C}$ & $4.77 \pm 0.33^{\mathrm{A}}$ & $6.35 \pm 0.47^{\mathrm{B}}$ & $6.23 \pm 1.40$ \\
\hline & BMR 3.6 & $9.30 \pm 0.55^{\mathrm{D}}$ & $7.97 \pm 0.24^{\mathrm{C}}$ & $7.45 \pm 0.54^{C}$ & $8.24 \pm 0.95$ \\
\hline & Mean of harvest age & $8.43 \pm 1.23$ & $6.37 \pm 2.26$ & $6.90 \pm 0.78$ & \\
\hline \multirow[t]{3}{*}{ Crude fiber (\%) } & Citayam & $35.04 \pm 1.24^{\mathrm{d}}$ & $35.40 \pm 2.46^{\mathrm{d}}$ & $34.56 \pm 1.45^{\mathrm{cd}}$ & $35.00 \pm 0.42$ \\
\hline & BMR 3.6 & $32.79 \pm 1.06^{\mathrm{bc}}$ & $29.65 \pm 0.79^{a}$ & $31.95 \pm 1.77^{\mathrm{b}}$ & $31.46 \pm 1.63$ \\
\hline & Mean of harvest age & $33.91 \pm 1.59$ & $32.52 \pm 4.07$ & $33.25 \pm 1.84$ & \\
\hline \multirow[t]{3}{*}{ TDN (\%) } & Citayam & $53.90 \pm 0.71$ & $54.36 \pm 2.22$ & $54.88 \pm 1.29$ & $54.38 \pm 0.49^{\mathrm{A}}$ \\
\hline & BMR 3.6 & $55.16 \pm 1.18$ & $55.16 \pm 1.10$ & $57.82 \pm 1.81$ & $56.05 \pm 1.53^{\mathrm{B}}$ \\
\hline & Mean of harvest age & $54.53 \pm 0.89$ & $54.76 \pm 0.57$ & $56.35 \pm 2.08$ & \\
\hline
\end{tabular}

Note: Means with different capital superscripts differ significantly $(\mathrm{P}<0.01)$; means with different superscripts differ significantly (P<0.05).

Table 3. In vitro fermentability of different types of sorghum silage and ration

\begin{tabular}{llccc}
\hline \multirow{2}{*}{ Variables } & \multicolumn{1}{c}{ Rations } & \multicolumn{2}{c}{ Types of sorghum silage } & \multirow{2}{*}{ Mean of rations } \\
\cline { 3 - 4 } & & Citayam & BMR 3.6 & $6.70 \pm 0.00$ \\
$\mathrm{nH}$ & Mixed legumes & $6.70 \pm 0.00$ & $6.70 \pm 0.00$ & $6.70 \pm 0.00$ \\
& Concentrate & $6.70 \pm 0.00$ & $6.70 \pm 0.00$ & $11.28 \pm 0.50$ \\
$\mathrm{NH}_{3}(\mathrm{mM})$ & Mean types of sorghum silage & $6.70 \pm 0.00$ & $6.70 \pm 0.00$ & $11.52 \pm 0.99$ \\
& Mixed legumes & $10.92 \pm 0.79$ & $11.64 \pm 0.23$ & \\
\multirow{2}{*}{ Total VFA $(\mathrm{mM})$} & Concentrate & $10.82 \pm 0.71$ & $12.22 \pm 0.82$ & $55.74 \pm 5.00$ \\
& Mean types of sorghum silage & $10.87 \pm 0.07^{\mathrm{A}}$ & $11.93 \pm 0.41^{\mathrm{B}}$ & $55.42 \pm 1.54$ \\
& Mixed legumes & $52.20 \pm 1.92$ & $59.28 \pm 4.53$ & \\
\hline
\end{tabular}

Note: Means in the same row with different superscripts differ significantly $(\mathrm{P}<0.01)$. 
tation products. Rumen buffering capacity is supported by bicarbonate and phosphate salts that are able to maintain the $\mathrm{pH}$ at a level of 6-7. Results of in vitro study by Amer et al.( 2012) on the two types of sorghum silage have no effect on rumen $\mathrm{pH}$ (6:49 to 6:53).

$\mathrm{NH}_{3}$ concentration on BMR 3.6 was greater than that of the Citayam. CP and TDN contents of the BMR 3.6 were higher and lower in $\mathrm{CF}$ than Citayam. $\mathrm{NH}_{3}$ production $(6-21 \mathrm{mM})$ depends on the solubility of dietary protein, the amount of dietary protein, the length of the feed in the rumen, and rumen $\mathrm{pH}$ (McDonald et al., 2010). The process of protein degradation into amino acids occurs outside the cell, whereas the process of amino acids degradation into ammonia occurs in the microbial cells. Addition of high contents of free amino acids from grass silages increased the concentration of $\mathrm{NH}_{3}$ (Gresner et al., 2015).

For ruminants, the main source of energy is VFA originating from the fermentation of carbohydrate by microbes in the rumen. Most of the materials are digested in the rumen and produce short chain fatty acids called VFA that are absorbed from the rumen wall to the circulation. Total VFA concentration of BMR 3.6 was higher indicating that the sorghum silage was more easily degraded in the rumen, but the total VFA produced was still below normal level (70-150 mM) (McDonald et al., 2010). Total VFA of sorghum silage reported by Amer et al. (2012) is also below normal i.e., 44.7-58.5 $\mathrm{mM}$.

Molar proportions of VFA are 0.65 acetic acid, 0.21 propionic acid, and 0.14 butyric acid depending on the type of feed consumed by the cattle. Acetic acid is produced in large quantities, about $20-50 \mathrm{~mol} / \mathrm{d}$ and propionic acid is usually produced one-third of acetic acid (McDonald et al., 2010). Rations and sorghum types had no effect on the concentration of propionic acid. The concentration of acetic acid in mixed legumes was higher than in concentrates. Fibrous feed would produce more acetic acid proportion while feed containing more easily fermentable carbohydrate such as concentrate would produce more propionic acid. The level of acetic acid found in this study was below standard, while the level of propionic acid was above the standard. Concentrate part of the ration produced higher butyric acid than mixed legumes because the content of CF and NFE of concentrate was lower than mixture of legumes, but the average concentration of butyric acid was still below normal. Fermentation of forage produces a larger ratio of A:P than that of concentrate. Mixed legumes yielded a greater ratio of A:P than concentrate.

BMR 3.6 produced more methane gas than the Citayam. Moss et al. (2000), stated that the acetic acid and butyric acid were precursor of $\mathrm{CH}_{4}$ production, but the formation of propionic acid could reduce the production of $\mathrm{CH}_{4}$ by re-channeling hydrogen gas in the rumen. The estimate of methane gas produced was relatively lower because propionic acid production was twice higher than normal. High concentrations of propionic acid could also be due to the content of lactic acid in the sorghum forage silage and bacteria Propionibacterium contained in the rumen. Propionic acid can be produced from sugar through lactic acid as an intermediate by Propionibacterium species. Propionibacterium can utilize lactic acid as a substrate faster than glucose (Tyree et al., 1991). Chen et al. (2012) suggested that the use of fibrous material plants as bioreactors, such as bagasse sugarcane, enhanced the production of propionic acid by Propionibacterium freudenreichii. The sorghum stem has similarities with bagasse sugarcane.

\section{Dynamics of Rumen Microbes}

Ration $(\mathrm{P}<0.05)$ and the type of sorghum $(\mathrm{P}<0.05)$ had significant effect on the population of protozoa in the rumen (Table 5). There was an interaction between rations and the type of sorghum for total bacterial population $(\mathrm{P}<0.05)$.

Tabel 4. Molar proportion of VFA, A:P ratio, and methane with different types of sorghum silage and ration

\begin{tabular}{|c|c|c|c|c|}
\hline \multirow{2}{*}{ Variables } & \multirow{2}{*}{ Rations } & \multicolumn{2}{|c|}{ Types of sorghum silage } & \multirow{2}{*}{ Mean of rations } \\
\hline & & Citayam & BMR 3.6 & \\
\hline \multirow{3}{*}{$\begin{array}{l}\text { Acetic acid } \\
(\% \mathrm{mM})\end{array}$} & Mixed legumes & $47.77 \pm 1.10$ & $47.42 \pm 1.31$ & $47.60 \pm 0.24^{\mathrm{b}}$ \\
\hline & Concentrate & $46.19 \pm 2.06$ & $45.47 \pm 2.28$ & $45.83 \pm 0.51^{\mathrm{a}}$ \\
\hline & Mean types of sorghum silage & $46.98 \pm 1.12$ & $46.45 \pm 1.38$ & \\
\hline \multirow{3}{*}{$\begin{array}{l}\text { Propionic acid } \\
(\% \mathrm{mM})\end{array}$} & Mixed legumes & $31.04 \pm 0.37$ & $30.39 \pm 0.19$ & $30.72 \pm 0.46$ \\
\hline & Concentrate & $31.09 \pm 0.70$ & $30.48 \pm 0.56$ & $30.78 \pm 0.43$ \\
\hline & Mean types of sorghum silage & $31.06 \pm 0.04$ & $30.43 \pm 0.06$ & \\
\hline \multirow{3}{*}{$\begin{array}{l}\text { Butyric acid } \\
(\% \mathrm{mM})\end{array}$} & Mixed legumes & $13.57 \pm 0.14$ & $13.92 \pm 0.28$ & $13.74 \pm 0.25^{\mathrm{A}}$ \\
\hline & Concentrate & $14.83 \pm 0.44$ & $15.32 \pm 0.84$ & $15.07 \pm 0.35^{\mathrm{B}}$ \\
\hline & Mean types of sorghum silage & $14.20 \pm 0.89$ & $14.62 \pm 0.99$ & \\
\hline \multirow[t]{3}{*}{ Ratio A: P } & Mixed legumes & $1.54 \pm 0.05$ & $1.56 \pm 0.03$ & $1.55 \pm 0.02^{b}$ \\
\hline & Concentrate & $1.49 \pm 0.10$ & $1.49 \pm 0.01$ & $1.49 \pm 0.00^{\mathrm{a}}$ \\
\hline & Mean types of sorghum silage & $1.51 \pm 0.04$ & $1.53 \pm 0.05$ & \\
\hline \multirow{3}{*}{$\begin{array}{l}\text { Methane } \\
(\mathrm{mM})\end{array}$} & Mixed legumes & $9.61 \pm 0.64$ & $10.98 \pm 0.43$ & $10.29 \pm 0.97$ \\
\hline & Concentrate & $9.86 \pm 1.03$ & $10.28 \pm 0.90$ & $10.07 \pm 0.30$ \\
\hline & Mean types of sorghum silage & $9.73 \pm 0.18^{a}$ & $10.63 \pm 0.49^{b}$ & \\
\hline
\end{tabular}

Note: Means with different capital superscripts differ significantly $(\mathrm{P}<0.01)$; means with different superscripts differ significantly $(\mathrm{P}<0.05)$. 
Giving mixed legumes improved protozoa population as compared to concentrates and BMR 3.6 improved protozoa population as compared to Citayam. All rations containing BMR 3.6 had better total bacterial population than those containing Citayam. The high population of protozoa and bacteria produced by BMR 3.6 in this study was due to the higher digestibility of BMR 5.6 than that of Citayam (Table 5). Total bacteria and protozoa in the normal range were $10^{9}-10^{10} \mathrm{CFU} / \mathrm{mL}$ and $10^{6}$ cells/mL. Fermentability level and digestibility of the ration are determined by the activity and the dynamics of microbes in the rumen. Better conditions in the rumen, improves dynamics and microbial activity in the rumen (McDonald et al., 2010).

Concentrate decreased protozoa population as compared with mixed legumes. This result could be related to the higher crude fat content in rations using concentrate (Table 1). The high crude fat in concentrate was contributed by the rice bran which had high fat content. Parrado et al. (2006) stated that the extract of rice bran had a fat component of $30 \%$ with oleic and linoleic acid as the major components. Abubakr et al. (2013) stated that the use of oils and fatty acids would be toxic to rumen protozoa. In line with the results of his research, palm byproduct lowered the population of protozoa. Wanapat \& Khampa (2006) stated the addition of fat from palm oil was able to reduce the population of the rumen protozoa.

\section{Dry and Organic Matters Digestibilities}

Type of sorghum had effect on dry matter digestibility $(\mathrm{P}<0.05)$, and all treatments had no effect on or- ganic matter digestibility (Table 6). BMR 3.6 had a greater digestibility as compared with Citayam. The increase in digestibility of BMR 3.6 was due to the lower lignin content as compared to Citayam. In BMR silage, the fraction of CF was primarily lignin and the lignin was lower as compared to the other type of sorghum (Miron et al., 2005). Carmi et al. (2006) stated that in all cases a decrease in lignin content in plant organs increased the dry matter digestibility. The high in vitro digestibility of BMR sorghum forage silage could be seen from the high degradation of nutritional content and the low of lignin content (Miron et al., 2007).

Sorghum silage digestibility was still relatively lower; it could be due to the proportion of diet containing sorghum forage silage form the age of $105 \mathrm{~d}$ (ages of maturation) that was up to $70 \%$. Zhang et al. (2015) stated the addition percentage of sweet sorghum silage in the feed decreased dry and organic matter digestibility. The addition of sweet sorghum silage up to $60 \%-80 \%$ combined with legume alfalfa silage $40 \%-20 \%$ resulted in vitro dry and organic matter digestibilities ranged from $49 \%-52 \%$ and $55 \%-58 \%$, respectively.

At the ages of maturation, the process of cellulose synthesis is in progress thereby increasing cellulose content. This increase relates to the establishment of a secondary walls, rich in cellulose in the stem and leaf tissue (Carmi et al., 2006), resulting in lower digestibility of forage. In the study of Di Marco et al. (2009), the digestibility of sorghum forage silage of BMR harvested at $110 \mathrm{~d}$ after planted was $57 \%$ after $48 \mathrm{~h}$ of incubation; the result was still relatively low.

Table 5. Rumen microbial populations treated with sorghum silage type and ration

\begin{tabular}{lllcr}
\hline \multirow{2}{*}{ Variables } & \multicolumn{1}{c}{ Rations } & \multicolumn{2}{c}{ Types of sorghum silage } & \multirow{2}{*}{ Mean of rations } \\
\cline { 3 - 4 } & & Citayam & BMR 3.6 & $5.26 \pm 0.02^{\mathrm{b}}$ \\
\hline Protozoa log cell/mL & Mixed legumes & $5.25 \pm 0.33$ & $5.28 \pm 0.30$ & $5.22 \pm 0.04^{\mathrm{a}}$ \\
& Concentrate & $5.20 \pm 0.32$ & $5.25 \pm 0.30$ & \\
& Mean types of sorghum silage & $5.22 \pm 0.04^{\mathrm{a}}$ & $5.27 \pm 0.02^{\mathrm{b}}$ & \\
Bacteria $\log$ CFU/mL & $9.29 \pm 0.05^{\mathrm{a}}$ & $10.46 \pm 0.62^{\mathrm{b}}$ & $9.88 \pm 0.83$ \\
& Mixed legumes & $9.35 \pm 0.04^{\mathrm{a}}$ & $10.35 \pm 0.58^{\mathrm{b}}$ & $9.85 \pm 0.71$ \\
& Concentrate & $9.32 \pm 0.04$ & $10.41 \pm 0.08$ & \\
\hline
\end{tabular}

Note: Means in the same row with different superscripts differ significantly $(\mathrm{P}<0.01)$.

Tabel 6. In vitro dry and organic matter digestibility with different types of sorghum silage and ration

\begin{tabular}{lllcr}
\hline \multirow{2}{*}{ Variables } & \multicolumn{1}{c}{ Rations } & \multicolumn{2}{c}{ Types of sorghum silage } & \multirow{2}{*}{ Mean of rations } \\
\cline { 3 - 4 } & & Citayam & BMR 3.6 & $53.51 \pm 3.07$ \\
\hline IVDMD (\%) & Mixed legumes & $51.34 \pm 6.07$ & $55.69 \pm 4.73$ & $52.89 \pm 3.04$ \\
& Concentrate & $50.74 \pm 0.75$ & $55.04 \pm 0.68$ & \\
IVOMD (\%) & Mean types of sorghum silage & $51.04 \pm 0.42^{\mathrm{a}}$ & $55.36 \pm 0.45^{\mathrm{b}}$ & $45.08 \pm 3.07$ \\
& Mixed legumes & $43.91 \pm 6.88$ & $46.24 \pm 6.88$ & $45.30 \pm 3.04$ \\
& Concentrate & $43.90 \pm 1.00$ & $46.71 \pm 1.00$ & \\
\hline
\end{tabular}

Note: Means in the same row with different superscripts differ significantly $(\mathrm{P}<0.01)$. IVDMD=in vitro dry matter digestibility; IVOMD= in vitro organic matter digestibility 


\section{CONCLUSION}

Based on silage quality, in vitro fermentability and digestibility studies by using rumen fluid of beef cattle, sorghum forage silage strain of BMR 3.6 harvested at $105 \mathrm{~d}$ had a very good quality of silage and mixed legumes could replace concentrate on sorghum forage silage-based diets. Mixed legumes did not influence the fermentability, microbial activity, and digestibility in the rumen.

\section{ACKNOWLEDGEMENT}

This experiment was funded by PT Kaltim Prima Coal, Indonesia.

\section{REFERENCES}

Abdelhadi, L. O. \& J. M. Tricarico. 2009. Effects of stage of maturity and microbial inoculation at harvest on nutritive quality and degradability of grain sorghum whole-plant and head-chop silages. Anim. Feed Sci. Technol. 152: 175185. http://dx.doi.org/10.1016/j.anifeedsci.2009.04.014

Abdullah, L. 2010. Herbage production and quality of shrub indigofera treated by different concentration of foliar fertilizer. Med. Pet. 33: 169-175. http://dx.doi.org/10.5398/ medpet.2010.33.3.169

Abdullah, L. \& Suharlina. 2010. Herbage yield and quality of two vegetative parts of indigofera at different times of first regrowth defoliation. Med. Pet. 33: 44-49.

Abubakr, A. R., A. R. Alimon, H. Yaakub, N. Abdullah, \& M. Ivan. 2013. Digestibility, rumen protozoa, and ruminal fermentation in goats receiving dietary palm oil by-products. J. Saudi Soc. Agric. Sci. 12: 147-154. http://dx.doi. org/10.1016/j.jssas.2012.11.002

Amer, S., F. Hassanat, R. Berthiaume, P. Seguin, \& A. F. Mustafa. 2012. Effects of water soluble carbohydrate content on ensiling characteristics, chemical composition and in vitro gas production of forage millet and forage sorghum silages. Anim. Feed Sci. Technol. 177: 23-29. http://dx.doi. org/10.1016/j.anifeedsci.2012.07.024

Anele, U. Y., O. M. Arigbede, K. H. Südekumb, A. O. Oni, A. O. Jolaosho, J. A. Olanite, A. I. Adeosun, P. A. Dele, K. A. Ike, \& O. B. Akinola. 2009. Seasonal chemical composition, in vitro fermentation and in sacco dry matter degradation of four indigenous multipurpose tree species in Nigeria. Anim. Feed Sci. Technol. 154: 47-57. http://dx.doi. org/10.1016/j.anifeedsci.2009.07.007

AOAC. 2007. Official Methods of Analysis of AOAC International, Association of Official Analysis Chemists International.

Carmi, A., Y. Aharoni, M. Edelstein, N. Umiel, A. Hagiladi, E. Yosef, M. Nikbachat, A. Zenou, \& J. Miron. 2006. Effects of irrigation and plant density on yield, composition and in vitro digestibility of a new forage sorghum variety, Tal, at two maturity stages. Anim. Feed Sci. Technol. 131: 121-133. http://dx.doi.org/10.1016/j.anifeedsci.2006.02.005

Chen, F., X. Feng, H. Xu, D. Zhang, \& P. Ouyang. 2012. Propionic acid production in a plant fibrous-bed bioreactor with immobilized Propionibacterium freudenreichii CCTCC M207015. J. Biotechnol. 164: 202-210. http://dx.doi. org/10.1016/j.jbiotec.2012.08.025

Contreras-Govea, F. E., R. E. Muck, G. a. Broderick, \& P. J. Weimer. 2013. Lactobacillus plantarum effects on silage fermentation and in vitro microbial yield. Anim. Feed Sci. Technol. 179: 61-68. http://dx.doi.org/10.1016/j.anifeedsci.2012.11.008
Emanuel, V., V. Adrian, P. Ovidiu, \& C. Gheorghe. 2005. Isolation of a Lactobacillus plantarum strain used for obtaining a product for the preservation of fodders. African J. Biotechnol. 4: 403-408.

Foster, J. L., A. T. Adesogan, J. N. Carter, A. R. Blount, R. O. Myer, \& S. C. Phatak. 2009. Intake, digestibility, and nitrogen retention by sheep supplemented with warmseason legume haylages or soybean meal. J. Anim. Sci. 87: 2899-2905. http://dx.doi.org/10.2527/jas.2009-1828

Gresner, N., A. Wichern, L. Lumpp, M. Hoedemaker, \& M. Höltershinken. 2015. Effects of grass silages with two levels of free amino acids on degradation of amino acids and fixation of nitrogen in bacterial protein in bovine ruminal fluid using the rumen simulation technique (Rusitec). Anim. Feed Sci. Technol. 202: 1-11. http://dx.doi. org/10.1016/j.anifeedsci.2014.12.012

Hartadi, H., S. Reksohadiprodjo, S. Lebdosukojo, A. D. Tillman, L. C. Kearl, \& L. E. Harris. 1980. Tables of Feed Composition for Indonesia. International Feedstuffs Institute Utah Agricultural Experiment Station, Utah State University Logan, Utah.

Hess, H. D., M. L. Mera, T. T. Tiemann, C. E. Lascano, \& M. Kreuzer. 2008. In vitro assessment of the suitability of replacing the low-tannin legume Vigna unguiculata with the tanniniferous legumes Leucaena leucocephala, Flemingia macrophylla or Calliandra calothyrsus in a tropical grass diet. Anim. Feed Sci. Technol. 147: 105-115. http://dx.doi. org/10.1016/j.anifeedsci.2007.09.012

Idikut, L., B. A. Arikan, M. Kaplan, I. Guven, A. I. Atalay, \& A. Kamalak. 2009. Potential nutritive value of swee corn as a silage crop with or without corn ear. J. Anim. Vet. Adv. 8: 734-741.

Jahanzad, E., M. Jorat, H. Moghadam, A. Sadeghpour, M. R. Chaichi, \& M. Dashtaki. 2013. Response of a new and a commonly grown forage sorghum cultivar to limited irrigation and planting density. Agric. Water Manag. 117: 62-69. http://dx.doi.org/10.1016/j.agwat.2012.11.001

Juma, H. K., S. A. Abdulrazak, R. W. Muinga, \& M. K. Ambula. 2006. Evaluation of Clitoria, Gliricidia and Mucuna as nitrogen supplements to Napier grass basal diet in relation to the performance of lactating Jersey cows. Livest. Sci. 103: 23-29. http://dx.doi.org/10.1016/j.livsci.2005.12.006

Kang, S., M. Wanapat, P. Pakdee, R. Pilajun, \& A. Cherdthong. 2012. Effects of energy level and Leucaena leucocephala leaf meal as a protein source on rumen fermentation efficiency and digestibility in swamp buffalo. Anim. Feed Sci. Technol. 174: 131-139. http://dx.doi.org/10.1016/j.anifeedsci.2012.03.007

Kearl, L. C. 1982. Nutrient Requirements of Ruminants in Developing Countries. Logan, Utah.

Keles, G. \& U. Demirci. 2011. The effect of homofermentative and heterofermentative lactic acid bacteria on conservation characteristics of baled triticale-Hungarian vetch silage and lamb performance. Anim. Feed Sci. Technol. 164: 21-28. http://dx.doi.org/10.1016/j.anifeedsci.2010.11.017

Lima, R., R. F. Díaz, A. Castro, S. Hoedtke, \& V. Fievez. 2011. Multifactorial models to assess responses to sorghum proportion, molasses and bacterial inoculant on in vitro quality of sorghum-soybean silages. Anim. Feed Sci. Technol. 164: 161-173. http://dx.doi.org/10.1016/j.anifeedsci.2011.01.008

Di Marco, O. N., M. A. Ressia, S. Arias, M. S. Aello, \& M. Arzadún. 2009. Digestibility of forage silages from grain, sweet and bmr sorghum types: Comparison of in vivo, in situ and in vitro data. Anim. Feed Sci. Technol. 153: 161-168. http://dx.doi.org/10.1016/j.anifeedsci.2009.06.003

McDonald, P., R. A. Edwards, J. F. D. Greenhalgh, C. A. Morgan, L. A. Sinclair, \& R. G. Wilkinson. 2010. Animal Nutrition. 7th ed. Prentice Hall, Pearson. Harlow, England; 
London, New York, Boston, San Fransisco, Toronto, Sydney, Tokyo, Singapore, Hong Kong, Seoul, Taipei, New Delhi, Cape Town, Madrid, Mexico City, Amsterdam, Munich, Paris, Milan.

Miron, J., E. Zuckerman, G. Adin, R. Solomon, E. Shoshani, M. Nikbachat, E. Yosef, A. Zenou, Z. G. Weinberg, Y. Chen, I. Halachmi, \& D. Ben-Ghedalia. 2007. Comparison of two forage sorghum varieties with corn and the effect of feeding their silages on eating behavior and lactation performance of dairy cows. Anim. Feed Sci. Technol. 139: 23-39. http://dx.doi.org/10.1016/j.anifeedsci.2007.01.011

Miron, J., E. Zuckerman, D. Sadeh, G. Adin, M. Nikbachat, E. Yosef, D. Ben-Ghedalia, A. Carmi, T. Kipnis, \& R. Solomon. 2005. Yield, composition and in vitro digestibility of new forage sorghum varieties and their ensilage characteristics. Anim. Feed Sci. Technol. 120: 17-32. http://dx.doi. org/10.1016/j.anifeedsci.2005.01.008

Moss, A. R., J. Jouany, \& J. Newbold. 2000. Methane production by ruminants: its contribution to global warming (Review article). Ann. Zootech 49: 231-253. http://dx.doi. org/10.1051/animres:2000119

Niderkorn, V., R. Baumont, A. le Morvan, \& D. Macheboeuf. 2011. Occurrence of associative effects between grasses and legumes in binary mixtures on in vitro rumen fermentation characteristics. J. Anim. Sci. 89: 1138-1145. http:// dx.doi.org/10.2527/jas.2010-2819

Ogimoto, K. \& S. Imai. 1981. Atlas of Rumen Microbiology. Japan Sci. Soc. Pub, Tokyo.

Parrado, J., E. Miramontes, M. Jover, J. F. Gutierrez, L. Collantes de Terán, \& J. Bautista. 2006. Preparation of a rice bran enzymatic extract with potential use as functional food. Food Chem. 98: 742-748. http://dx.doi.org/10.1016/j. foodchem.2005.07.016

Pereira, D. H., O. G. Pereira, B. C. da Silva, M. I. Leão, S. D. C. Valadares Filho, F. H. M. Chizzotti, \& R. Garcia. 2007. Intake and total and partial digestibility of nutrients, ruminal $\mathrm{pH}$ and ammonia concentration and microbial efficiency in beef cattle fed with diets containing sorghum (Sorghum bicolor (L.) Moench) silage and concentrate in different ratios. Livest. Sci. 107: 53-61. http://dx.doi.org/10.1016/j. livsci.2006.09.002

Ridwan, R., I. Rusmana, Y. Widyastuti, K. G. Wiryawan, B. Prasetya, M. Sakamoto, \& M. Ohkuma. 2015. Fermentation characteristics and microbial diversity of tropical grasslegumes silages. Asian-Australas. J. Anim. Sci. 28: 511-8.

Rocateli, A. C., R. L. Raper, K. S. Balkcom, F. J. Arriaga, \& D. I. Bransby. 2012. Biomass sorghum production and components under different irrigation/tillage systems for the southeastern U.S. Ind. Crops Prod. 36: 589-598.
Steel, R. G. D., \& J. H. Torrie. 1997. Principles and Procedures of Statistics. McGraw-Hill, New York.

Tabacco, E., F. Righi, a Quarantelli, \& G. Borreani. 2011. Dry matter and nutritional losses during aerobic deterioration of corn and sorghum silages as influenced by different lactic acid bacteria inocula. J. Dairy Sci. 94: 1409-1419. http:// dx.doi.org/10.3168/jds.2010-3538

Tan, H. Y., C. C. Sieo, N. Abdullah, J. B. Liang, X. D. Huang, \& Y. W. Ho. 2011. Effects of condensed tannins from Leucaena on methane production, rumen fermentation and populations of methanogens and protozoa in vitro. Anim. Feed Sci. Technol. 169: 185-193. http://dx.doi.org/10.1016/j. anifeedsci.2011.07.004

Thomas, M. E., J. L. Foster, K. C. McCuistion, L. A. Redmon, \& R. W. Jessup. 2013. Nutritive value, fermentation characteristics, and in situ disappearance kinetics of sorghum silage treated with inoculants. J. Dairy Sci. 96: 7120-31. http://dx.doi.org/10.3168/jds.2013-6635

Tilley, J. M. A. \& R. A. Terry. 1963. A two-stage technique for the in vitro digestion of forage crops. Grass Forage Sci. 18: 104-111. http://dx.doi.org/10.1111/j.1365-2494.1963. tb00335.x

Tohno, M., H. Kobayashi, K. Tajima, \& R. Uegaki. 2012. Straindependent effects of inoculation of Lactobacillus plantarum subsp. plantarum on fermentation quality of paddy rice (Oryza sativa L. subsp. japonica) silage. FEMS Microbiol. Lett. 337: 112-119. http://dx.doi.org/10.1111/15746968.12014

Tyree, R. W., E. C. Clausen, \& J. L. Gaddy. 1991. The production of propionic-acid from sugars by fermentation through lactic-acid as an intermediate. J. Chem. Technol. Biotechnol. 50: 157-166. http://dx.doi.org/10.1002/jctb.280500203

Wanapat, M. \& S. Khampa. 2006. Effect of mineralized solid palm fat and feeding pattern on ruminal ecology and digestibility of nutrients in dairy steers fed on urea-treated rice straw. Pakistan J. Nutr. 5: 319-324. http://dx.doi. org/10.3923/pjn.2006.319.324

Yuan, X., G. Guo, A. Wen, S. T. Desta, J. Wang, Y. Wang, \& T. Shao. 2015. The effect of different additives on the fermentation quality, in vitro digestibility and aerobic stability of a total mixed ration silage. Anim. Feed Sci. Technol. 207: 41-50. http://dx.doi.org/10.1016/j.anifeedsci.2015.06.001

Zhang, S. J., A. S. Chaudhry, A. Osman, C. Q. Shi, G. R. Edwards, R. J. Dewhurst, \& L. Cheng. 2015. Associative effects of ensiling mixtures of sweet sorghum and alfalfa on nutritive value, fermentation and methane characteristics. Anim. Feed Sci. Technol. 206: 29-38. http://dx.doi. org/10.1016/j.anifeedsci.2015.05.006 